This item was submitted to Loughborough's Research Repository by the author.

Items in Figshare are protected by copyright, with all rights reserved, unless otherwise indicated.

\title{
A multi-body head-and-neck model for simulation of rear impact in cars
}

PLEASE CITE THE PUBLISHED VERSION

PUBLISHER

(C) Professional Engineering Publishing

VERSION

VoR (Version of Record)

LICENCE

CC BY-NC-ND 4.0

REPOSITORY RECORD

Himmetoglu, Selcuk, Memis Acar, Andrew J. Taylor, and Kaddour Bouazza-Marouf. 2019. "A Multi-body Headand-neck Model for Simulation of Rear Impact in Cars". figshare. https://hdl.handle.net/2134/4514. 
This item was submitted to Loughborough's Institutional Repository (https://dspace.lboro.ac.uk/) by the author and is made available under the following Creative Commons Licence conditions.

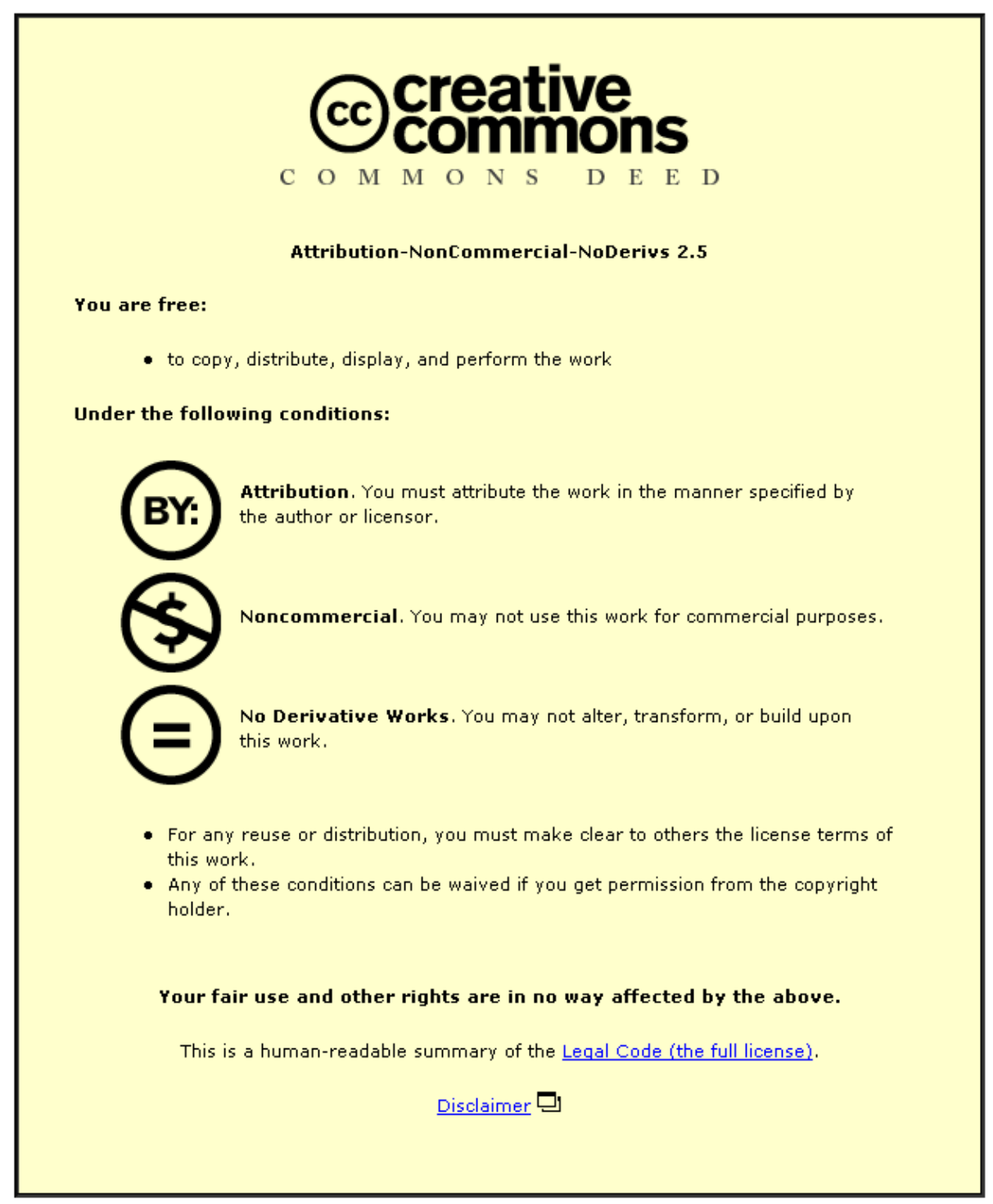

For the full text of this licence, please go to: http://creativecommons.org/licenses/by-nc-nd/2.5/ 


\title{
A multi-body head-and-neck model for simulation of rear impact in cars
}

\author{
S Himmetoglu*, M Acar, A J Taylor, and K Bouazza-Marouf \\ Wolfson School of Mechanical and Manufacturing Engineering, Loughborough University, Loughborough, UK
}

The manuscript was received on 18 October 2006 and was accepted after revision for publication on 12 February 2007.

DOI: 10.1243/09544070JAUTO467

\begin{abstract}
This paper presents the development and validation of a 50th percentile male multi-body head-and-neck model, aimed primarily at analysing rear impact and the resulting whiplash injury effects. The objective is to design a computationally efficient model behaving like a human head and neck in the case of a rear impact. The volunteer sled tests performed by the Japanese Automobile Research Institute (JARI) have been used for the validation of the head-neck model for low-speed rear-impact analysis. The presented approach for the multibody head-and-neck model is simple, effective, and capable of producing biofidelic responses. The results show that the model can represent with a high degree of accuracy the rear-impact response of a human.
\end{abstract}

Keywords: multi-body head-and-neck model, whiplash, rear impact, volunteer and cadaver experiments, validation, muscle behaviour

\section{INTRODUCTION}

Multi-body dynamics, finite element (FE) analysis, or a combination of the two, can be used to design a head-and-neck model. In the literature, there are more FE models than multi-body models [1]. FE models need a great deal of computational power, but can provide detailed information about tissue deformations and injury prediction. Multi-body models can also include many anatomical details while being computationally efficient. This makes them suitable for parameter variation and optimization analyses. In these models, the head and vertebrae are modelled as rigid bodies and soft tissues (intervertebral discs, facet joints, ligaments, muscles) are usually modelled as massless springdamper elements. Such multi-body models are capable of producing biofidelic responses $[\mathbf{1}, \mathbf{2}]$. Displacements of the head with respect to the torso, accelerations, intervertebral motions, and neck forces/moments can provide good predictions for whiplash injury. These variables are in fact used in various injury criteria that have been reported in the literature [3].

\footnotetext{
* Corresponding author: Wolfson School of Mechanical and Manufacturing Engineering, Loughborough University, Loughborough, UK. email: s.himmetoglu@lboro.ac.uk
}

The objective of this study is to design a biofidelic and computationally efficient multi-body head-and-neck model that can be used as part of a rear-impact human-body model. The model has been validated against published data from the Japanese Automobile Research Institute (JARI) volunteer experiments.

\section{BACKGROUND}

\subsection{Multi-body head-and-neck models}

There are several multi-body head-and-neck models in the literature and an overview of these models is presented in Table 1. Jakobsson et al. [4] presented a multi-body head-and-neck model which formed the cervical section of the complete spine designed to work in the sagittal (fore/aft) plane. The headneck system comprised revolute joints which applied resistance to motion according to specified torque versus rotation functions. The time-dependency of the muscle reflexes was not considered and the validation of this model included only qualitative comparisons made for a single-impact speed condition.

The head-and-neck model of de Jager [5] is a prominent study in the literature. In his first model, 'the global model', all the mechanical behaviour of 


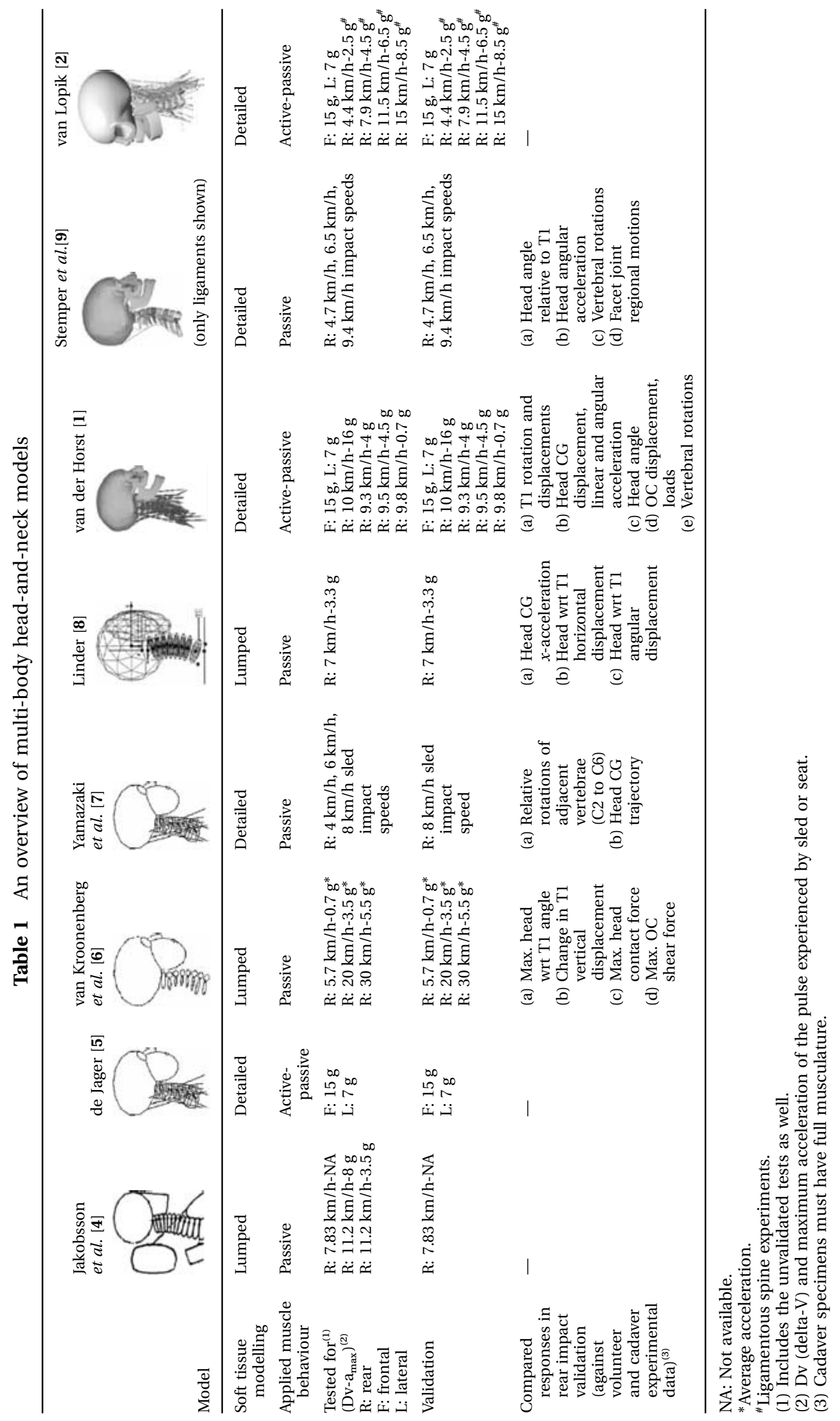


the soft tissues was lumped into the intervertebral joints. The second model was detailed, comprising linear viscoelastic intervertebral discs, non-linear viscoelastic ligaments, active muscles, and frictionless facet joints. Muscles were modelled as straightline elements. This model was validated against frontal and lateral impacts and showed reasonable responses. Later, van Kroonenberg et al. [6] used de Jager's global model for the head and neck in their multi-body rear-impact human-body model. The responses for low- and high-severity cases were compared approximately with the available rear-impact sled tests conducted with volunteers and human cadavers. However, the validation of this model was incomplete due to lack of experimental data available at the time. Following this, Yamazaki et al. [7] improved de Jager's detailed model [5] by changing the joint resistance properties. The model was optimized by using data from one volunteer from the sled tests performed by JARI with a standard seat and at an impact speed of $8 \mathrm{~km} / \mathrm{h}$.

Recently, improvements have been achieved in the responses of rear-impact multi-body head-and-neck models. Linder [8] developed a mathematical model of a rear impact dummy neck that was used in the development of the BioRID dummy, or anthropometric test device (ATD). The dummy neck was supplemented by two muscle substitutes in the form of cables in the front and back of the neck. Sensitivity analysis revealed that a combination of elastic stiffness and damping in the muscle substitutes, along with non-linear joint stiffness, produced a better response than that of the available neck models of the time. It was noted that without using muscle substitutes, a neck with only revolute joints was not able to provide biofidelic responses.

An improvement to de Jager's detailed model [5] was also made by van der Horst [1]. The improved model was then integrated into the human body model built in Madymo [10] (the integrated multibody FE package of TNO Automotive, Crash Safety Centre). Muscles were able to follow the curvature of the neck, providing more realistic muscle force lines of action. The model was first validated for frontal and lateral impacts by specifying the motion of $\mathrm{T} 1$ (the first thoracic vertebra). For rear-impact analysis, the complete human body was simulated rather than an isolated head-and-neck model. First, rear-impact sled tests involving volunteers and cadavers were simulated with passive muscles. For the cadaver experiments, the effects of post-mortem changes in passive muscle properties were studied by an additional simulation. In the rigid-seat volunteer experiments without head restraint and seat-belt, realizing active muscle behaviour was shown to be necessary, since substantial differences were observed between simulations done with active and passive muscle behaviour. However, in rear-impact simulations with a standard seat with head restraint, both the passive and active models showed reasonableto-poor correlation with the volunteer data.

Stemper et al. [9] built a model of a head and neck using Madymo, incorporating segmented contractile muscles. Active muscle effects were not considered. The model was validated using global, segmental, and facet joint kinematic corridors developed from a series of cadaver head-neck complexes with intact skin and musculature. The specimens were rigidly attached to a mini-sled at the base of the neck (T1) and the impact delivered a horizontal acceleration to this mini-sled [11].

Another detailed multi-body head-and-neck model was developed by van Lopik [2] and implemented in MSC VisualNastran 4D. Muscles, with both active and passive behaviour, were represented by connections of linear actuators which allowed them to curve around the vertebrae during neck bending. The model was validated for frontal and lateral impacts. For both impact modes, the inclusion of active muscle behaviour resulted in closest agreement with the experimental data. Whiplash simulations revealed that the influence of active muscle response did not significantly affect the head-neck kinematics of an initially unaware occupant, but would affect the forces developed in the cervical soft tissues.

The model of van der Horst [1] stands out as having a more complete validation with regard to the others. However, the responses of this model were not satisfactory at all times, as indicated by the author [1]. The model of Linder [8] was validated against volunteer data [12] and showed satisfactory responses. However, the responses in the vertical direction were not compared and the model was optimized for a single crash speed only. The BioRID II P3 dummy that originated from Linder's study [8] was later shown to have responses close to an average volunteer in low-severity rear-impact sled tests $[\mathbf{1 3}]$.

Table 1 indicates that, in validating multi-body head-and-neck models for rear impact, head and T1 kinematics and occipital condyles (OC) loading have been mostly used. Validation with regard to cervical vertebra displacements is very limited. There is also a limited range of severity for rear-impact validation. Some tests, especially the higher severity ones, were simulated without any validation against volunteer 
and intact cadaver experimental data. The scarcity of volunteer and cadaver experiments with adequate data and the difficulties of accurate measurement are the main reasons for the limitations.

\subsection{Volunteer and cadaver experiments for rear-impact validation}

Numerous volunteer and cadaver experiments are published in the literature; however, the extent of studies that are suitable for validation of rear-impact models is limited. In most cases, information about the experimental set-up and the complete time history of responses are not given or well documented. The volunteer sled tests can only involve lowseverity impacts for the safety of subjects. Cadaver experiments can be a good source of validation for higher severity cases, but the suitable ones are few in number and their severities are only slightly higher than volunteer experiments. Furthermore, cadavers usually represent older subjects and they have no muscular tone and reflexes. It is therefore clear that cadavers are not able fully to represent actual human behaviour.

Bearing these limitations in mind, a list of volunteer and cadaver experiments suitable for the complete validation of 50th percentile male human rear-impact response is presented in Table 2. From this information, the JARI volunteer and Pendulum cadaver experiments have been found to be the most suitable ones for rear-impact validation. Although there is enough data from the LAB cadaver experiments to validate simulation studies, the human subjects did not represent a 50th percentile male, thus the head mass and moments of inertia were relatively low. The JARI, LAB, and Pendulum experiments used either a rigid seat or no seat. This helps the modelling process by eliminating the effect of seat- and headrestraint properties that would otherwise be involved in the responses.

Table 2 Volunteer and cadaver experiments for 50th percentile male human rear-impact response validation

\begin{tabular}{|c|c|c|c|c|}
\hline Experiment & Whiplash II & JARI & TRL & AZT \\
\hline Reference & $\begin{array}{l}\text { Hynd and van Ratingen } \\
{[\mathbf{1 4}]}\end{array}$ & Davidsson et al. $[\mathbf{1 3}]$ & Hynd et al. [15] & $\begin{array}{l}\text { van den Kroonenberg } \\
\quad \text { et al. }[\mathbf{1 6}]\end{array}$ \\
\hline Subject & Volunteer & Volunteer & Volunteer & Volunteer \\
\hline $\begin{array}{l}\text { Number of subjects } \\
\text { and gender }\end{array}$ & $2 \mathrm{M}, 3 \mathrm{~F}$ & $7 \mathrm{M}$ & $10 \mathrm{M}$ & $7 \mathrm{M}, 3 \mathrm{~F}$ \\
\hline Sitting position & $\mathrm{N}$ & $\mathrm{N}, \mathrm{OOP}$ & $\mathrm{N}$ & $\mathrm{N}$ \\
\hline Seat type & $\begin{array}{l}\text { Test seat covered with } \\
\text { foam }\end{array}$ & $\begin{array}{l}\text { Rigid (R), } \\
\text { Standard (S) }\end{array}$ & Test seat covered with foam & Standard car seat \\
\hline Number of tests & 10 & $9(\mathrm{~N}), 3(\mathrm{OOP})$ & 10 & 10 \\
\hline Average mass (kg) & 74 & 71 & 77.5 & $\begin{array}{l}75(68 \text { to } 92)(\mathrm{M}) \\
59(56 \text { to } 62)(\mathrm{F})\end{array}$ \\
\hline Average height (cm) & 167 & $176(\mathrm{~N}), 177$ (OOP) & 179 & $\begin{array}{l}180(168 \text { to } 194)(\mathrm{M}) \\
168(164 \text { to } 176)(\mathrm{F})\end{array}$ \\
\hline Average age (years) & 35 (18 to 43$)$ & $26(\mathrm{~N}), 24(\mathrm{OOP})$ & 26.4 & $\begin{array}{l}29(18 \text { to } 41)(\mathrm{M}) \\
21(17 \text { to } 24)(\mathrm{F})\end{array}$ \\
\hline Head restraint & Yes & No & Yes & Yes \\
\hline Belt & Lap and shoulder belt & No & Four-point seat belt & $\begin{array}{l}\text { Three-point belt with } \\
\text { retractor }\end{array}$ \\
\hline Pulse Dv-max. acc & $\begin{array}{l}7 \mathrm{~km} / \mathrm{h}-3.5 \mathrm{~g} \\
9 \mathrm{~km} / \mathrm{h}-4 \mathrm{~g}\end{array}$ & $\begin{array}{l}9.3 \mathrm{~km} / \mathrm{h}-3.62 \mathrm{~g}(\mathrm{R}, \mathrm{N}) \\
8.6 \mathrm{~km} / \mathrm{h}-3.9 \mathrm{~g}(\mathrm{~S}, \mathrm{~N}) \\
7.4 \mathrm{~km} / \mathrm{h}-2.64 \mathrm{~g}(\mathrm{R}, \mathrm{OOP}) \\
7.0 \mathrm{~km} / \mathrm{h}-2.82 \mathrm{~g}(\mathrm{~S}, \mathrm{OOP})\end{array}$ & $7 \mathrm{~km} / \mathrm{h}-2 \mathrm{~g}$ & $9.5 \mathrm{~km} / \mathrm{h}-4.5 \mathrm{~g}$ \\
\hline $\begin{array}{l}\text { Presented responses } \\
\text { suitable for rear } \\
\text { impact validation }\end{array}$ & $\begin{array}{l}\text { Head CG trajectory } \\
\text { Head angle } \\
\text { Head CG acceleration } \\
\text { Head angular } \\
\text { acceleration } \\
\text { T1 trajectory } \\
\text { T1 angle } \\
\text { T1 acceleration }\end{array}$ & $\begin{array}{l}\text { Head angle } \\
\text { Head CG } x \text {-acceleration } \\
\text { Head angular acceleration } \\
\text { T1 } x-z \text { displacements, } \\
\text { angle, } x-z \text { acceleration } \\
\text { OC wrt T1 } x-z \\
\text { displacement } \\
\text { OC forces/moments } \\
\text { Iliac crest } x-z \\
\text { displacement } \\
\text { Distance between T1 } \\
\text { and iliac crest }\end{array}$ & $\begin{array}{l}\text { Head angle } \\
\text { Head CG } x-z \text { displacement } \\
\text { Head CG } x \text {-acceleration } \\
\text { T1 angle, } x-z \text { displacement } \\
\text { T1 } x \text {-acceleration } \\
\text { Pelvis } x \text {-acceleration } \\
\text { Seatback press distributions }\end{array}$ & $\begin{array}{l}\text { T1 trajectory, angle } \\
\text { Head angle } \\
\text { Head CG } x-z \text { displacement } \\
\text { wrt T1 } \\
\text { Head CG } x \text {-acceleration } \\
\text { Head angular acceleration } \\
\text { OC forces/moments } \\
\text { OC } x-z \text { displacement } \\
\text { wrt T1 } \\
\text { Head restraint impact } \\
\text { forces }\end{array}$ \\
\hline
\end{tabular}

$\mathrm{N}$ : Normal or in-position driving posture.

OOP: Out-of-position driving posture. 
Table 2 (Continued)

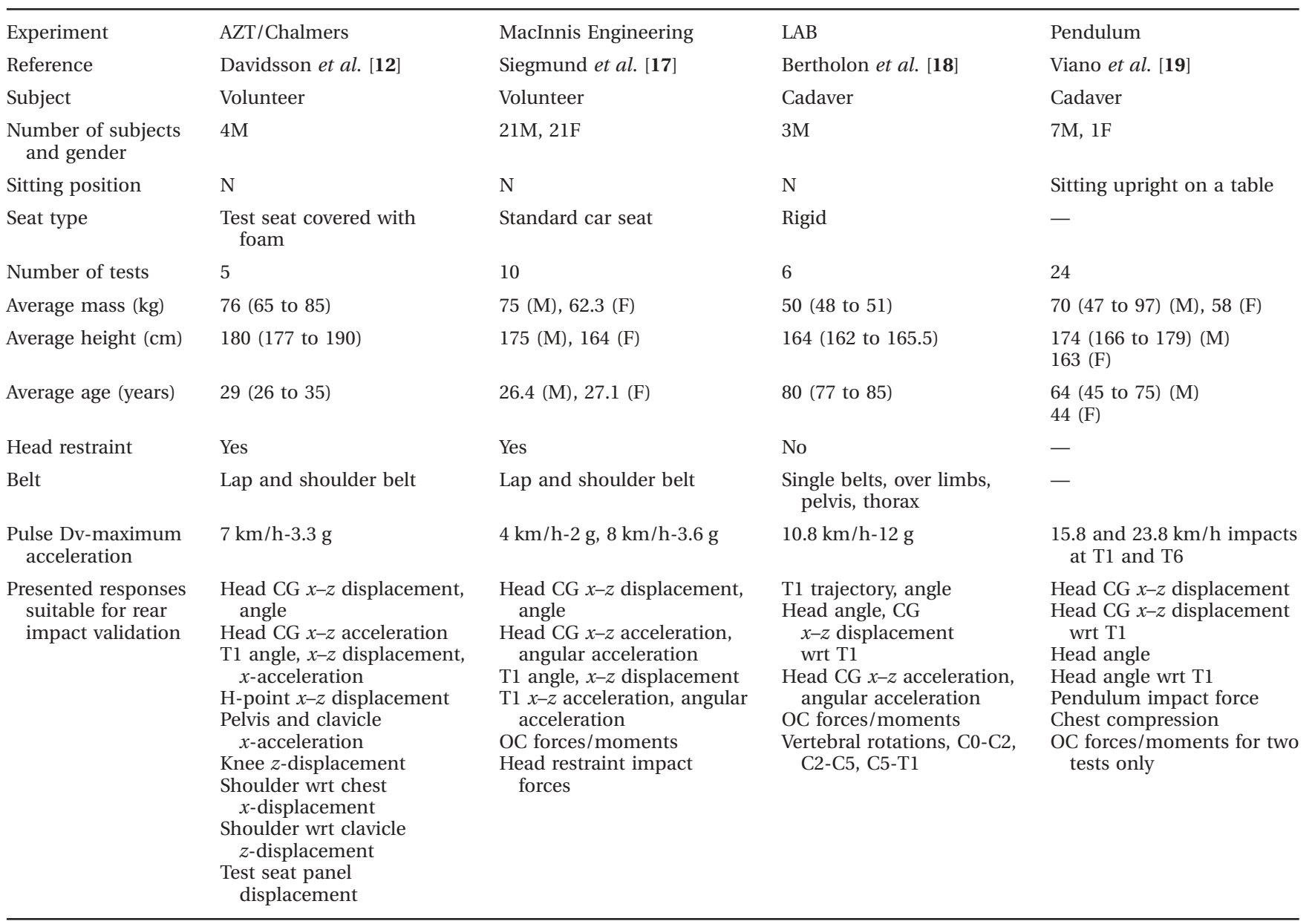

$\mathrm{N}$ : Normal or in-position driving posture.

OOP: Out-of-position driving posture.

\subsection{The JARI rigid-seat volunteer experiments}

The JARI test method is described in some detail as it provided much of the validation data for the proposed multi-body model. In these experiments, seven healthy 50 th percentile male volunteers $(25 \pm 4$ years of age) were subjected to rear impacts. A rigid wooden seat with no head restraint was mounted on a sled sliding on a long rail at an angle of $10^{\circ}$ with the horizontal as shown in Fig. 1. The volunteers were asked to assume a normal seating posture with the Frankfort plane of the head oriented horizontally. When viewed in the sagittal plane, the Frankfort plane appears as a line that passes through the external ear canal and across the top of the lower bone of the eye socket, as shown in Fig. 2. At the end of the rail, the sled engaged an oil damper at an impact speed of $8 \mathrm{~km} / \mathrm{h}$, resulting in a delta-V (Dv) of $9.3 \mathrm{~km} / \mathrm{h}[\mathbf{1 3}]$. The set-up was designed to replicate previous low-speed rear-end car collision experiments [20]. The resulting crash pulse is given in Fig. 3.

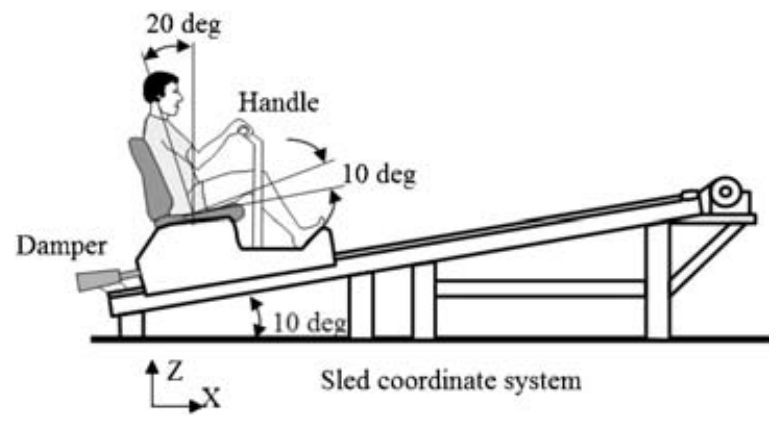

Fig. 1 JARI Volunteer test set-up (adapted from [13])

Film targets and biaxial accelerometers were attached to the head and to the skin overlying the T1 spinous process. Similarly, film targets were also attached to the sternum, iliac crest, and the $\mathrm{T} 1$ vertebra centre. X-ray images of the instrumented volunteer head and upper torso were used to locate the positions of the centre of gravity (C.G.) of the head, OC, and T1 with respect to the sensors. A head anatomical coordinate system was defined whose 


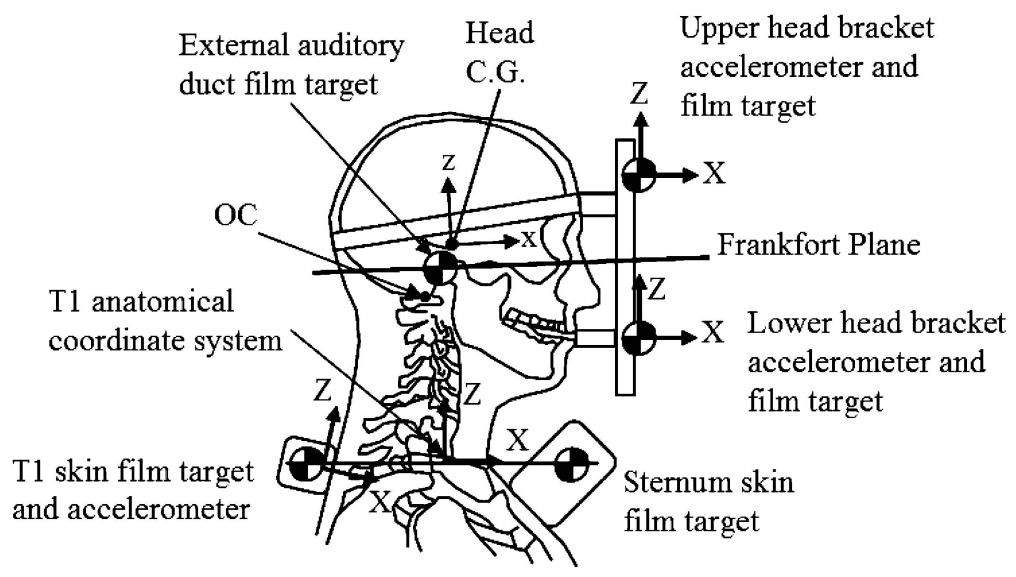

Fig. 2 Head and upper torso instrumentation (adapted from [13])

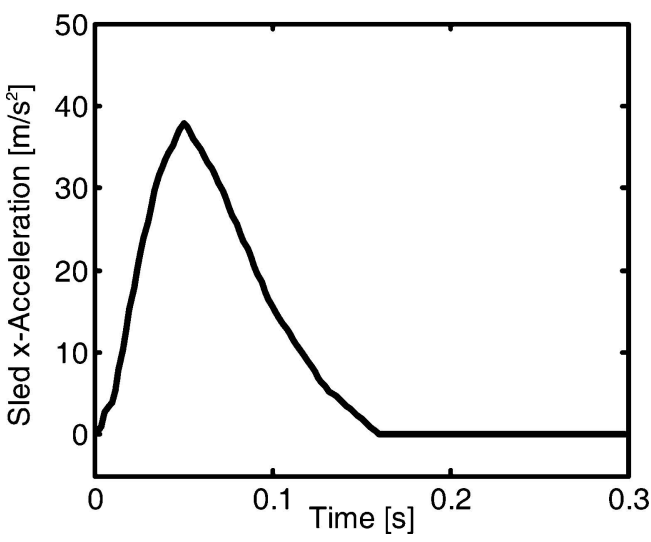

Fig. 3 Average sled $x$ acceleration [13]

centre was located at the head C.G. The $x$ axis was defined to be positive in the forward direction and parallel to that line defined by the Frankfort plane while the $z$ axis was defined to be positive in the upward direction. A T1 accelerometer coordinate system was defined, centred on the $\mathrm{T} 1$ spinous process. A $\mathrm{Tl}$ anatomical coordinate system was also defined whose centre was on the line connecting the sternum and T1 skin-film target centres. T1 $x$ and $z$ accelerations were recorded by $\mathrm{T} 1$ accelerometers and $\mathrm{T} 1$ rotation was calculated by using $\mathrm{T} 1$ and sternum skin-film targets as shown in Fig. 2. Electromyography (EMG) measurements indicated that most of the volunteers were relaxed before the impact.

\section{MODEL DEVELOPMENT}

The multi-body model reported in this paper is composed of a head, seven neck segments and a body representing $\mathrm{T} 1$ as shown in Fig. 4(a). The neck segments have identical geometry and represent

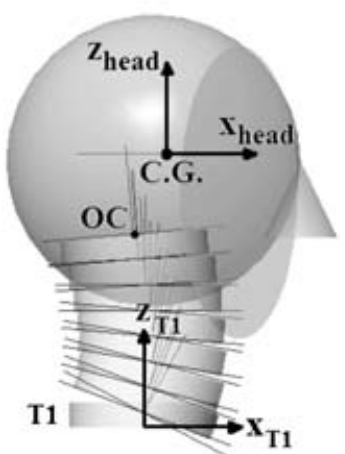

(a)

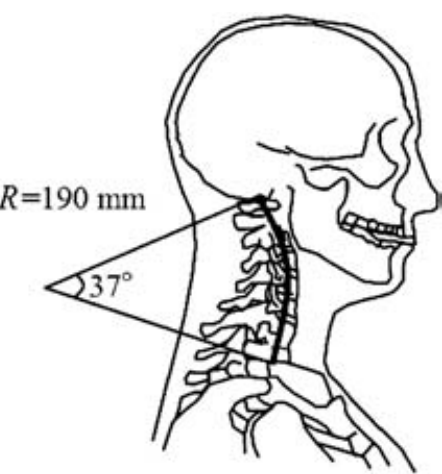

(b)
Fig. 4 (a) Multi-body head-and-neck model in its initial configuration. (b) Arc approximating the initial configuration $[\mathbf{8}, \mathbf{2 1}]$

the vertebrae $\mathrm{C} 1$ to $\mathrm{C} 7$ from top to bottom. The inertial properties of each neck segment represent the equivalent mass and moments of inertia of the vertebra and the surrounding soft tissues. The system is driven by specifying the motion at $\mathrm{T} 1$. The bodies are connected by revolute joints producing resistive torques opposing the motion. These intervertebral joint torques designate the equivalent resistance of soft tissues at each joint. For modelling purposes only, the model allows fictitious penetrations of neck segments. The penetrations do not affect the dynamics of the system. The model was developed by using the MSC VisualNastran 4D multi-body dynamics simulation package.

The initial configuration of the model corresponds to a 50th percentile male occupant's head and neck in normal driving posture with the head looking forward. As shown in Fig. 4(b), an arc having a $190 \mathrm{~mm}$ radius and a sector of $37^{\circ}$, as drawn between OC and C7 lower end plate, was shown to be a good approximation for the curvature of the neck 
$[\mathbf{8}, 21]$. The drawn arc represents a common type of neck curvature in occupants with a normal driving posture [22].

In the head and neck system, the body frame (i.e. coordinate system) of each vertebra is placed at the geometrical centre $\left(\mathrm{O}_{i}\right)$ of the main vertebral body as shown in Fig. 5. The $x$ axis of each body frame is selected to be parallel to the lower end plate of the corresponding vertebra. The positions of the head and vertebrae in the sagittal plane are specified with respect to the lower body (defined as $\operatorname{body}_{(i)}$ ) by the coordinates $s_{x}$ and $s_{z}$ measured in the frame of $\operatorname{body}_{(i)}$. Similarly, the orientation of body ${ }_{(i-1)}$ with respect to body $(i)$ is specified by the coordinate $\theta$. The position of the C.G. of body ${ }_{(i)}$ is specified by the coordinates $g_{x}$ and $g_{z}$ measured in the frame of body $_{(i)}$. For each body, the moments of inertia are expressed in a separate coordinate system with an origin at the C.G. The axes of this coordinate system are parallel to the body frame axes. The initial con-

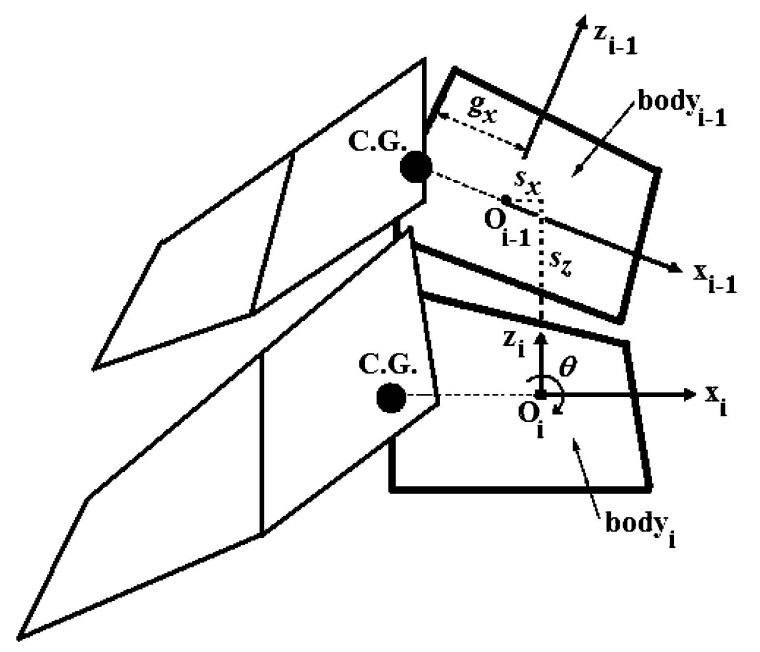

Fig. 5 Definition of body axes and positions. The boundaries of the main vertebral body are shown in dark (adapted from [1]) figuration, geometrical, and inertial properties are given in Table 3. The body names from $\mathrm{Cl}$ to $\mathrm{C} 7$ correspond to the neck segments, whereas $\mathrm{C} 0$ represents the head.

The neck segments of the multi-body model were designed to have the same geometry for simplicity. The relative orientations of the human neck given in Table 3 and the arc specified in Fig. 4(b) were used to position the neck segments, as shown in Fig. 6. Compared to the human neck, the relative orientations of $\mathrm{C} 1$ and $\mathrm{C} 2$ were slightly modified such that the arc approximately cuts the neck segments in half. This geometry resulted in a height of $17.4 \mathrm{~mm}$ for each neck segment. The intervertebral joints are placed at the intersections of the arc and the neck segments. The segments have the inertial properties given in Table 3, but are assumed to have a uniform density distribution. This assumption well approximates the positions of the centres of gravity of the neck segments.

It is a difficult issue to define the axis of rotations between adjacent vertebrae. The reason is that the locations of instantaneous axes of rotation (IAR) change throughout the motion and this change also depends on the type and severity of the loading [5, 23-25]. Several researchers $[\mathbf{2 3}, \mathbf{2 4}, \mathbf{2 6}]$ recorded IAR locations by using lateral X-rays when subjects voluntarily moved their heads between full flexion and full extension. Average IAR locations and corresponding standard deviations were found to be similar in these studies [23, 24, 26] (see Fig. 7). On the other hand, studies on IARs under dynamic loading conditions are scarce in the literature. JARI studies $[\mathbf{2 0}, \mathbf{2 5}, \mathbf{2 7}, \mathbf{2 8}]$ showed that the cervical spine appeared to be bent at the C5-C6 segment when the S-shaped curvature developed in volunteers subjected to rear-impact sled testing. However, the IARs of the C5-C6 segment were investigated only and they differed significantly from the voluntary IARs.

Table 3 The initial configuration, geometrical, and inertial properties of a 50th percentile male human head-neck (adapted from [5]). The last column shows the relative orientations in the multi-body head-and-neck model

\begin{tabular}{|c|c|c|c|c|c|c|c|c|c|c|}
\hline \multirow[b]{2}{*}{ Body } & \multirow[b]{2}{*}{ Mass $(\mathrm{kg})$} & \multicolumn{3}{|c|}{$\begin{array}{l}\text { Principal moments of } \\
\text { inertia }\left(\mathrm{kg} . \mathrm{cm}^{2}\right)\end{array}$} & \multicolumn{2}{|c|}{$\begin{array}{c}\text { Position of body frame } \\
\text { origin (mm) }\end{array}$} & \multicolumn{2}{|c|}{ Position of CG (mm) } & \multicolumn{2}{|c|}{ Relative orientation $\theta$ (deg) } \\
\hline & & $I_{x x}$ & $I_{y y}$ & $I_{z z}$ & $s_{x}$ & $s_{z}$ & $g_{x}$ & $g_{z}$ & Human neck & MultiB. neck \\
\hline $\mathrm{C} 0$ & 4.6 & 180 & 240 & 221 & -4.0 & 20.0 & 27.0 & 43.0 & 0 & 5.0 \\
\hline $\mathrm{C} 1$ & 0.22 & 2.2 & 2.2 & 4.2 & 0 & 16.5 & -7.7 & 0.0 & 0 & -1.2 \\
\hline $\mathrm{C} 2$ & 0.25 & 2.5 & 2.5 & 4.8 & -3.3 & 18.7 & -7.7 & 0.0 & 0 & -3.8 \\
\hline $\mathrm{C} 3$ & 0.24 & 2.4 & 2.4 & 4.6 & -4.0 & 17.8 & -7.8 & 0.0 & -5.3 & -5.3 \\
\hline $\mathrm{C} 4$ & 0.23 & 2.3 & 2.3 & 4.4 & -3.3 & 17.2 & -7.9 & 0.0 & -4.7 & -4.7 \\
\hline C5 & 0.23 & 2.3 & 2.3 & 4.5 & -2.8 & 17.4 & -8.1 & 0.0 & -5.2 & -5.2 \\
\hline C6 & 0.24 & 2.4 & 2.4 & 4.7 & -2.0 & 18.4 & -8.3 & 0.0 & -5.6 & -5.6 \\
\hline C7 & 0.22 & 2.2 & 2.2 & 4.3 & 6.4 & 16.8 & -8.2 & 0.0 & 20.8 & 20.8 \\
\hline $\mathrm{T} 1$ & - & - & - & - & 0 & 0 & - & - & 0 & 0 \\
\hline
\end{tabular}



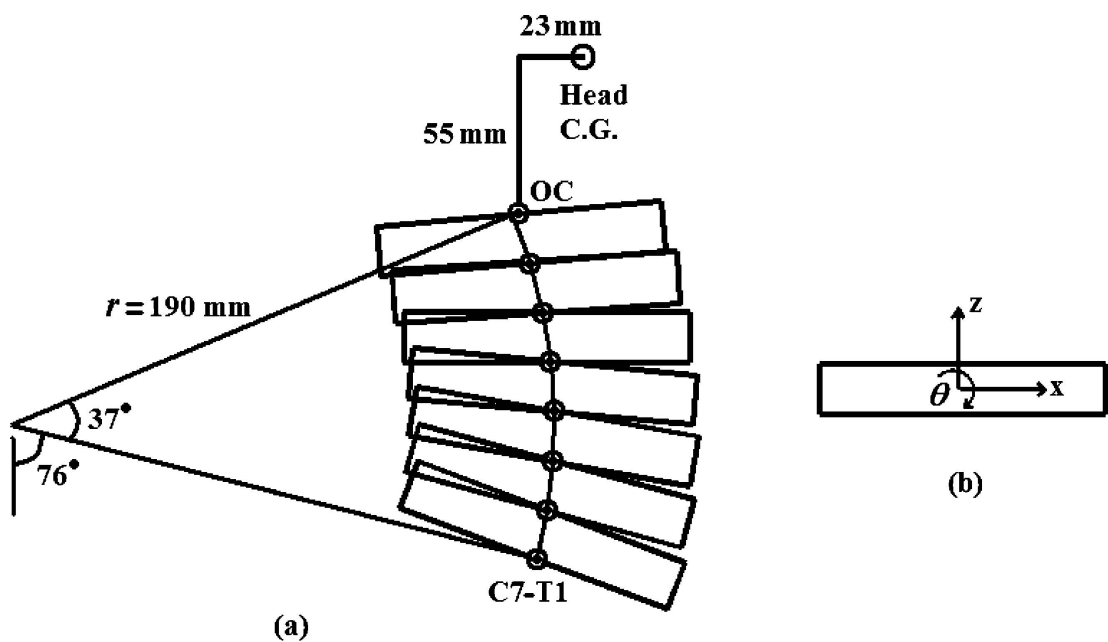

(b)

Fig. 6 (a) Neck curvature. (b) Neck segment frame axes

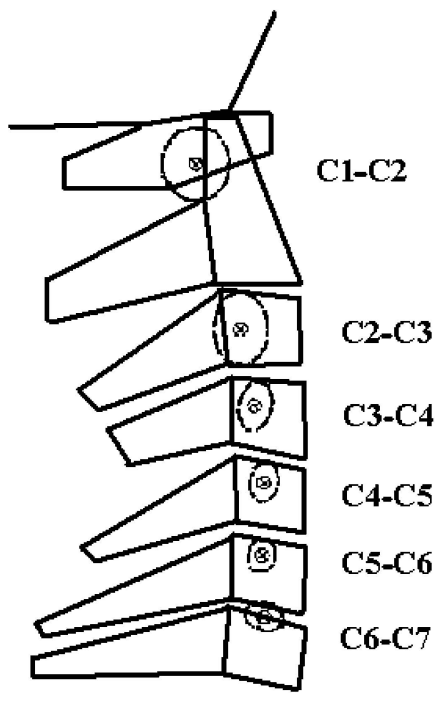

Fig. 7 Average IAR locations and standard deviations (adapted from [26])

Considering the above findings, there is no precise selection of IARs between adjacent vertebra that can represent the motion for different loadings and severities. The interactions of soft tissue and bodies are complex and impact conditions force the head and neck to behave in an unnatural way. Considering the very limited information on IAR locations in rear impact and the satisfactory responses of the BioRID dummy [13], it should be an acceptable approximation to place the intervertebral joints on the specified arc which in fact passes close to the voluntary (normal) flexion/extension IARs.

Rotational stiffnesses for the intervertebral joints were derived from the non-linear torque versus angle relation presented by Jakobsson et al. [4], as shown in Fig. 8. This function was based on quasi-static experiments and adjusted to integrate the contribution of muscles. However, it does not include the effects of muscle contraction. The viscoelastic feature and the dynamic stiffening behaviour of the soft tissues are realized by rotational damping coefficients.

Active muscle behaviour was investigated by Kingma et al. [29] who analysed the kinematics and muscle activity using rear-impact volunteer sled tests. It was observed that when there is a higher muscle activity, as in the case of muscle precontraction and anticipation of the impact, head displacements and velocities are reduced by 30-35 per cent when compared with the responses of relaxed and unaware volunteers. Ono et al. [20] observed the same differences between relaxed and precontraction cases in another set of JARI volunteer sled tests. Similar differences were also observed between active (human

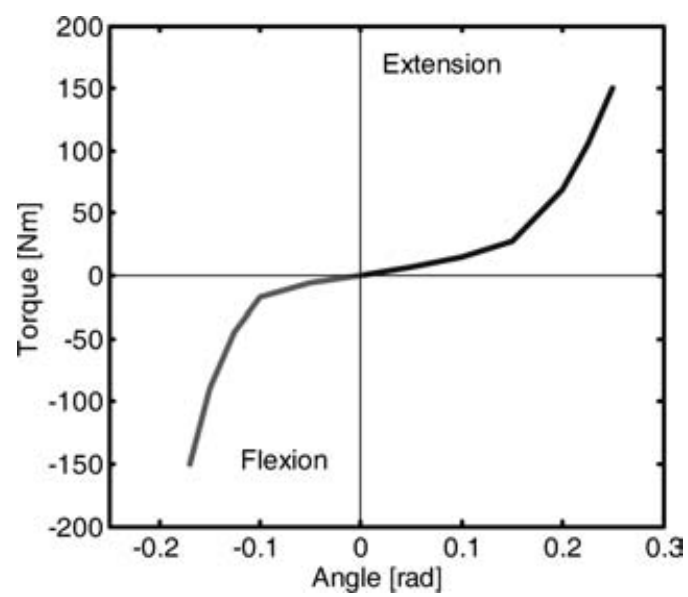

Fig. 8 Rotational stiffness of the intervertebral joints [4] 


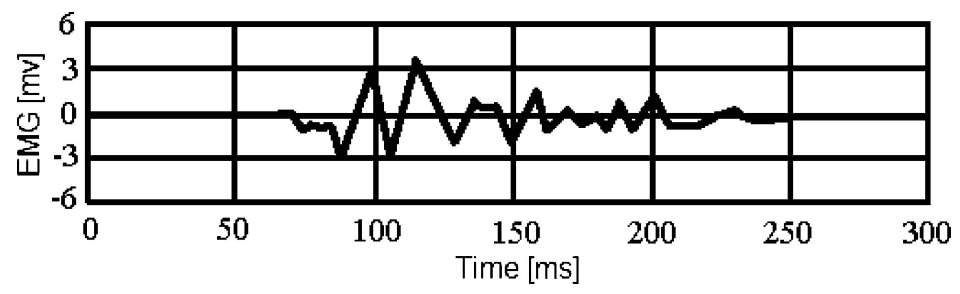

Fig. 9 Typical EMG response of SCM muscles in JARI experiments [20]

volunteer) and passive (cadaver) muscle behaviour under the same frontal impact conditions [30].

Figure 9 shows a typical EMG response for the sternocleidomastoid (SCM) muscles obtained in JARI experiments [20, 27], at an impact speed of $8 \mathrm{~km} / \mathrm{h}$. EMG activity for the SCM muscles was found to be substantially higher than for the other muscles; therefore, this muscle group was dominant in active muscle behaviour. Similar results were also found by other researchers $[\mathbf{2 9}, \mathbf{3 1}]$ with regard to contraction amplitudes of various muscles, their time variation, and reaction times.

Considering these findings, increasing damping in accordance with the muscle activity pattern better simulates active muscle behaviour and has the potential to reduce head rotation and head angular velocities at the same time. It is reasonable to express the damping coefficient function as a direct function of time, not as a function of head to $\mathrm{T} 1$ rotation. Damping plays a crucial role in obtaining satisfactory responses. A time-varying damping coefficient function based on a typical EMG response time history such as that shown in Fig. 9 was found to represent better the JARI volunteer responses throughout the motion. Figure 10 shows five different phases of the damping coefficient function. Between 0 to $75 \mathrm{~ms}$, no significant active muscle response occurs. At around $75 \mathrm{~ms}$, muscle discharge (mainly SCM) starts. Maximum EMG response is achieved at around $100 \mathrm{~ms}$ and maintained until $150 \mathrm{~ms}$. The muscular discharge decreases between 150-250 ms and almost disappears after $250 \mathrm{~ms}$.

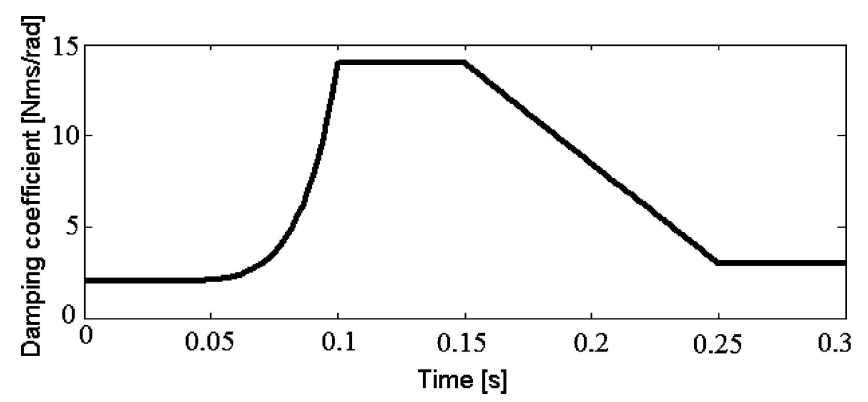

Fig. 10 Damping coefficient variation
For simplicity, the same stiffness and damping properties have been used for all the intervertebral joints. A good agreement between the JARI volunteer responses and the model has been achieved by using a time-varying damping coefficient and a scaled version of the non-linear stiffness function (based on cadaver experiments), in which the torque values are multiplied by a factor of 0.75 to better represent human response.

\section{MODEL VALIDATION}

\subsection{Validation of the multi-body head-and-neck model}

The multi-body head-and-neck model developed has been validated against JARI volunteer experiments by simulating the rear-impact sled-testing conditions explained in section 2. Figure 11 shows the mean values of $\mathrm{T} 1$ accelerations and rotation obtained from JARI volunteer sled tests, together with their upper and lower limits, which corresponded to mean \pm standard deviation (SD). The mean values have been calculated and used as inputs for the T1 motion.

A detailed set of responses that compare the responses of JARI volunteers and the multi-body head-and-neck model are shown in Figs 12-14. The complete set of JARI volunteer responses are provided in reference $[\mathbf{1}]$ and are shown by the grey lines. For the model validation, several responses have been analysed. The $\mathrm{T} 1$ trajectory and rotation are displayed with respect to the sled. The head angle is displayed both with respect to the sled and T1. The OC with respect to $\mathrm{T} 1$ displacements are expressed in the $\mathrm{T} 1$ anatomical coordinate system. The head C.G. $x$ acceleration and head angular acceleration are expressed in the head coordinate system.

The motion of the head-and-neck model is illustrated in Fig. 15. Overall, the model responses show good agreement with the volunteer data and are within the upper and lower limits. The important 

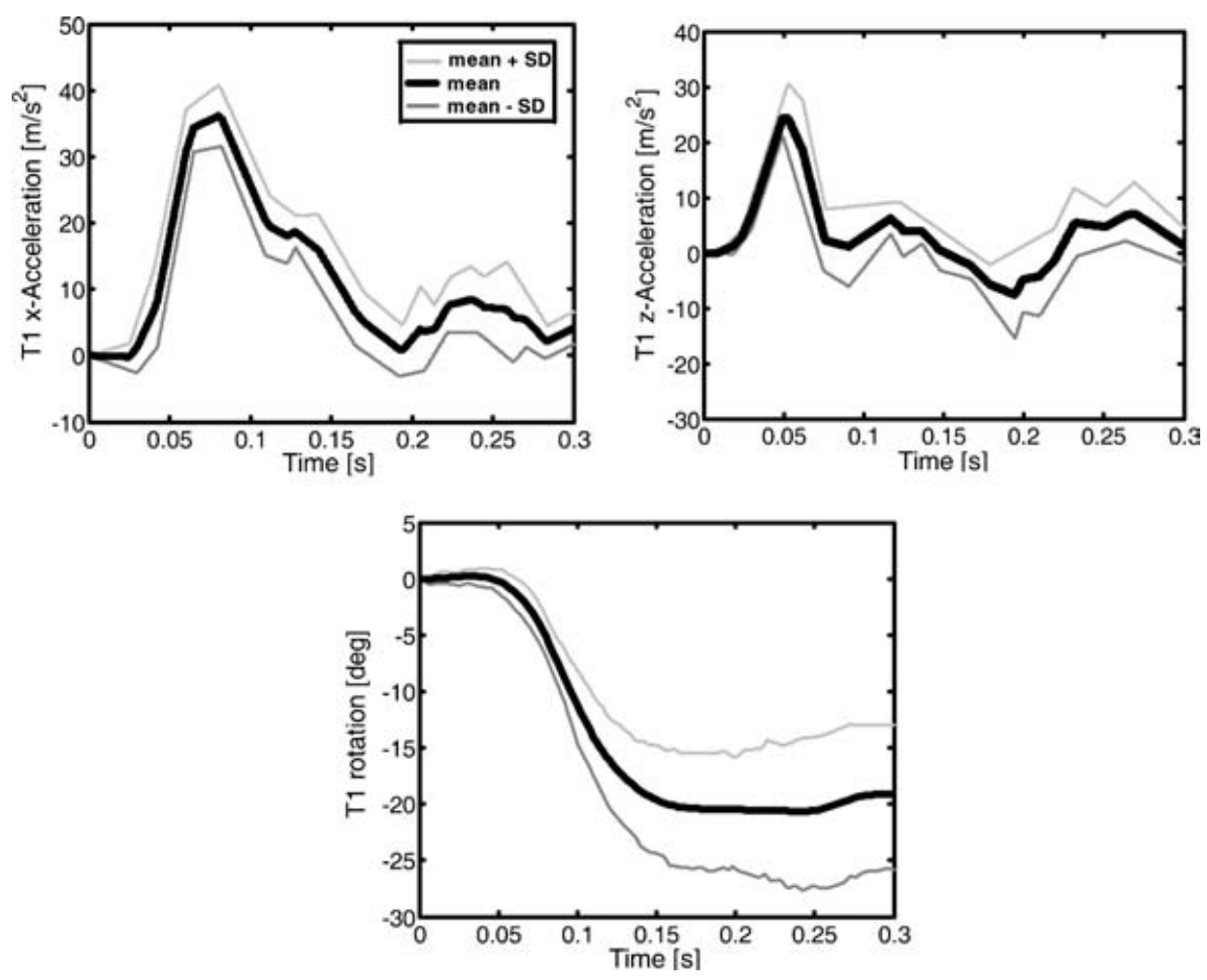

Fig. 11 T1 rotation and accelerations (mean \pm SD) (adapted from [13])
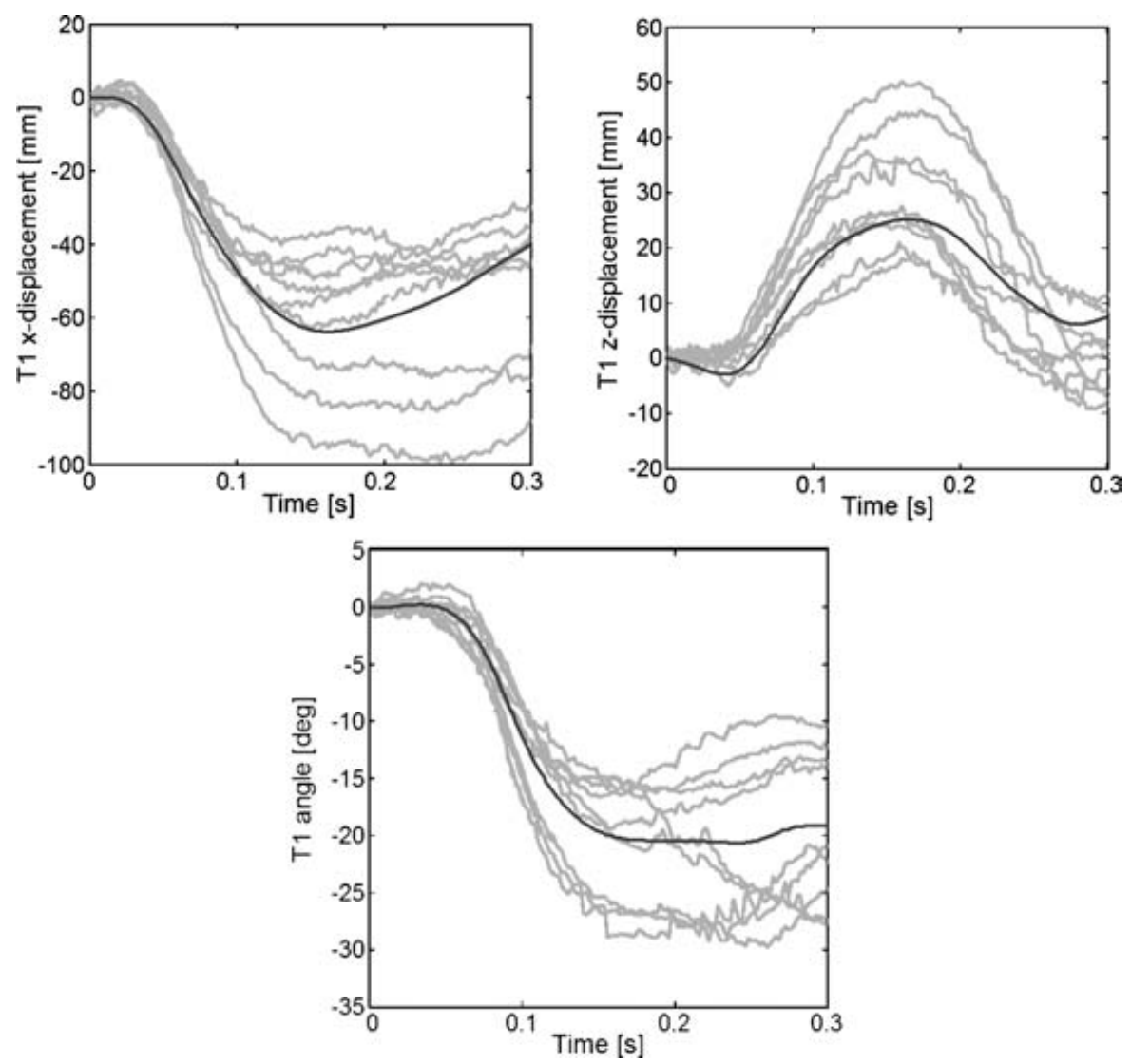

Fig. 12 T1 displacements (model versus JARI volunteer responses) 

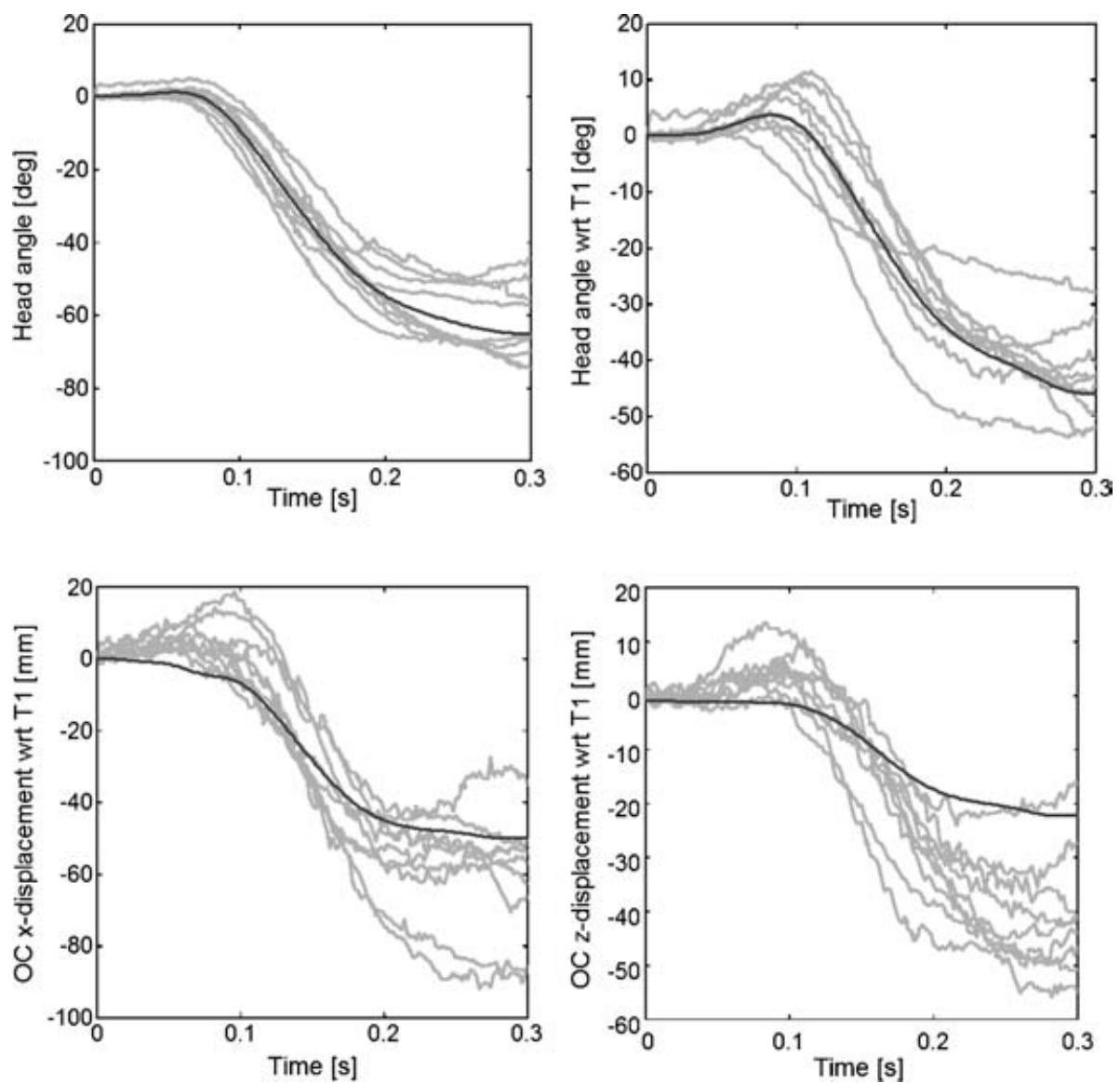

Fig. 13 Head displacements (model versus JARI volunteer responses)
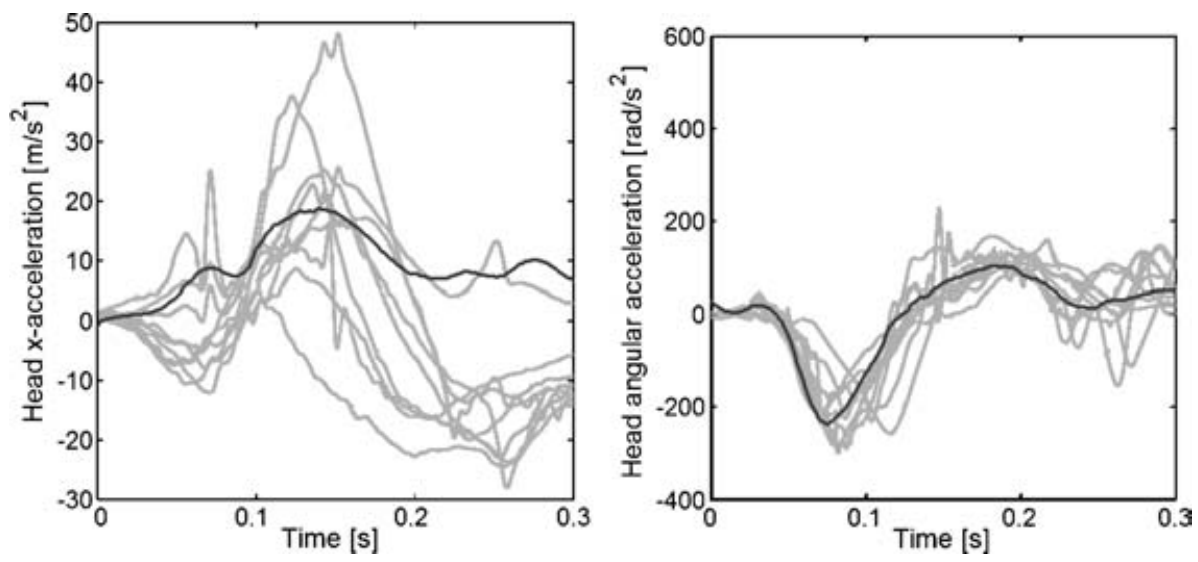

Fig. 14 Head accelerations (model versus JARI volunteer responses)
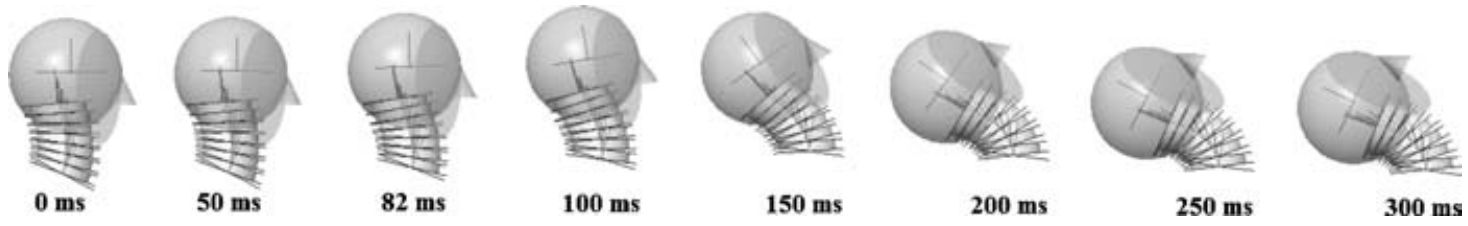

Fig. 15 Motion of the multi-body head-and-neck model 
parameters such as peak values and times, slope values and change times, starting times, rise times, and duration of extension are obtained successfully. The peak values and response pattern of the accelerations also agree well with the volunteer data.

\subsection{Comparison with other studies}

The responses of the developed model have been compared with the responses of other models and dummies that were subjected to the same impact, as described in section 2 . The comparative graphs are presented in Figs 16 to 18. All the responses of other models and dummies are displayed where available. BioRID II P3 $3_{(1)}$ and $\mathrm{H}$ III (Hybrid III) responses are provided by Davidsson et al. [13]. BioRID II $\mathrm{P} 3_{(2)}$ responses are given by Viano and Davidsson [32]. TNO responses are the results of a detailed head-neck model by van der Horst [1] , which was integrated into the TNO human body model. The displayed responses for TNO indicate the best agree- ment achieved by a parameter variation analysis in which the prestress, reflex time, and activation levels of flexor, extensor, and SCM muscle groups were tuned.

\section{CONCLUSIONS}

The rigorously validated multi-body head-and-neck model presented in this study has a neck with lumped properties. Using a set of stiffness and damping parameters for the intervertebral joints and without containing separate muscles, it is able to represent true muscle behaviour by simulating the effects of muscle contraction as a function of time. The model produces biofidelic behaviour and its response shows the precision of a detailed headand-neck model. Its overall response is superior when compared with the currently used models and dummies, and yet the presented approach is simple, effective, and computationally very efficient.
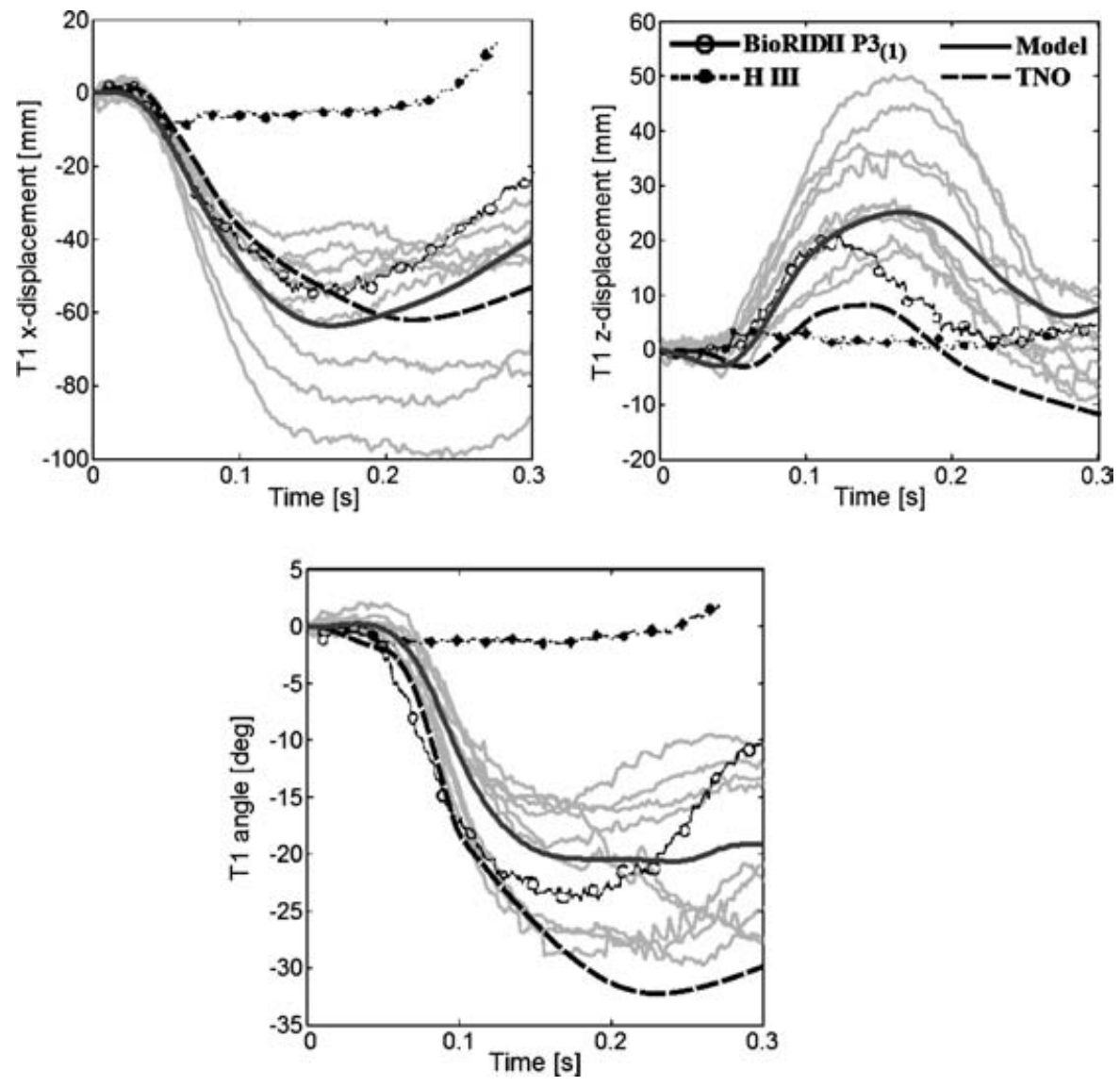

Fig. 16 T1 displacements (model versus other studies) $\left(-\bigcirc-\right.$ BioRIDII P3 $3_{(1)}$, - - - - - HIII, - Model, -- TNO, -- - BioRIDII P3 $(2)$ 

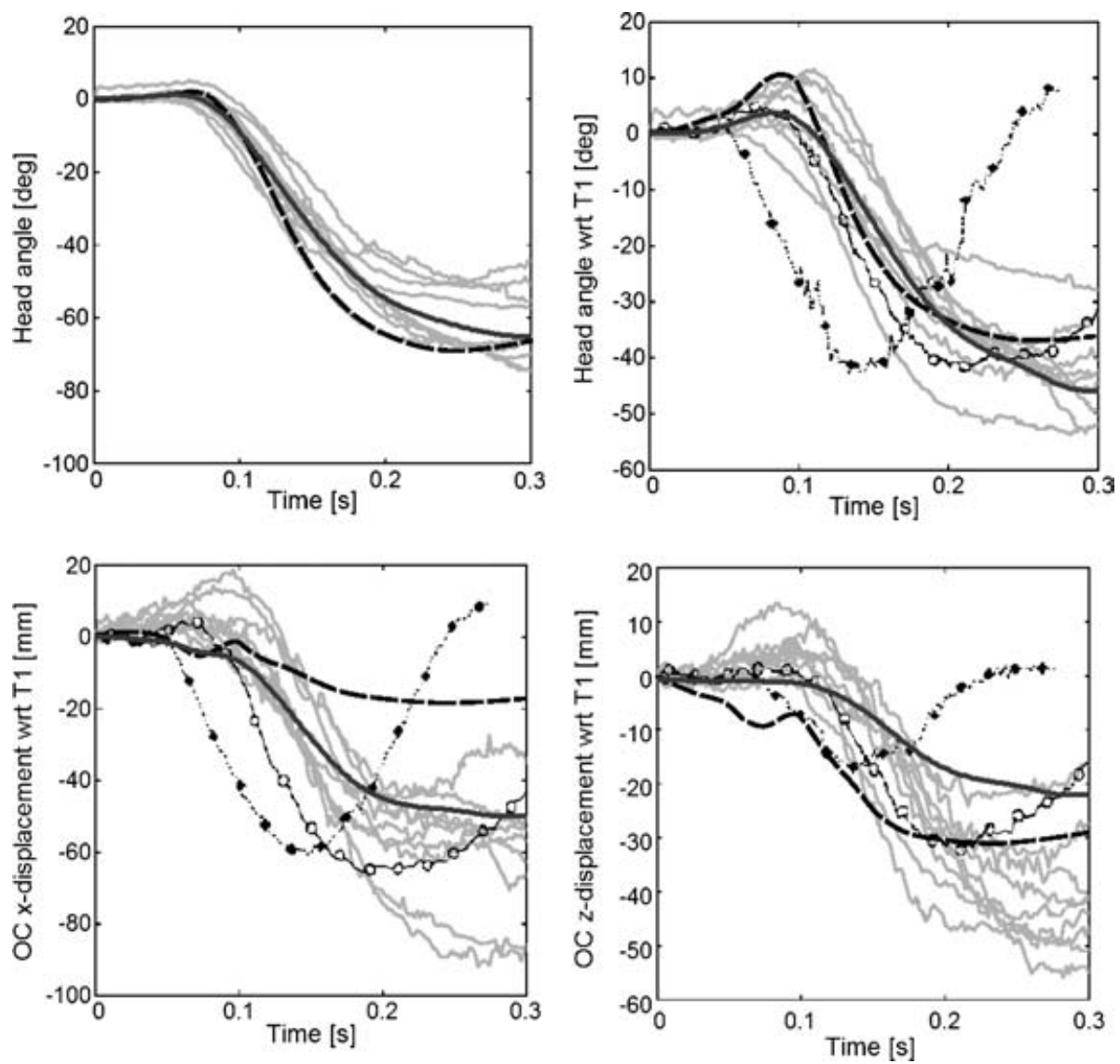

Fig. 17 Head displacements (model versus other studies) (-O- BioRIDII P3 $3_{(1)}$, - - - - HIII, - Model, -- TNO, - - - BioRIDII P3 $(2)$
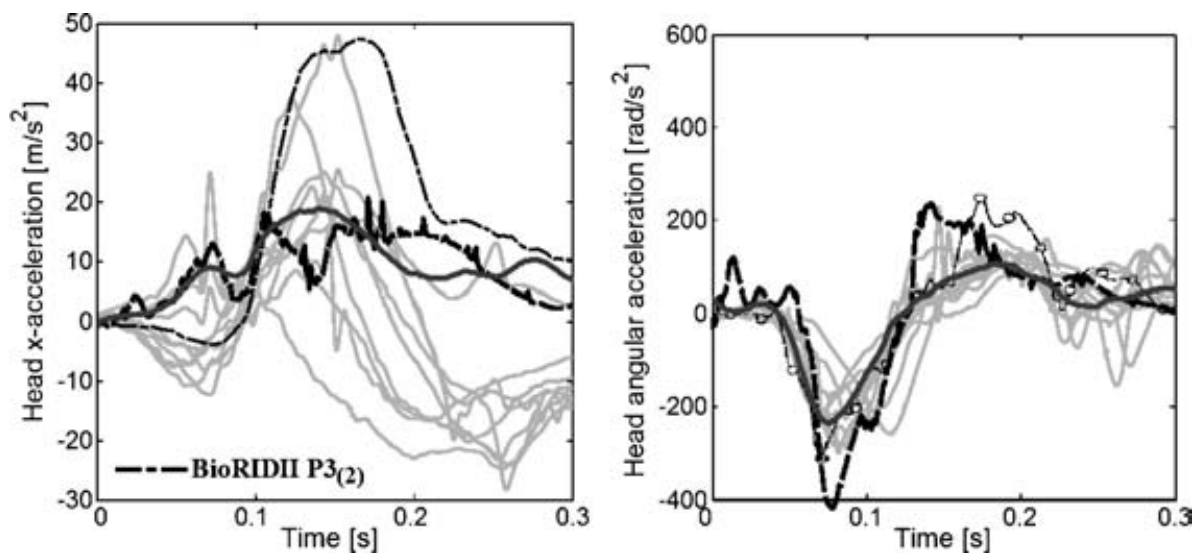

Fig. 18 Head accelerations (model versus other studies) (-O- BioRIDII P3 $3_{(1)}$, - - - - - HIII, - Model, -- TNO, - - - BioRIDII P3 $\left.{ }_{(2)}\right)$

The model can therefore simulate the rear-impact response of a human with a high degree of accuracy and, hence, it can be economically used as the headneck section of a rear-impact human-body model to compare accurately crash scenarios and has the potential of predicting injury.

\section{REFERENCES}

1 van der Horst, M. J. Human head neck response in frontal, lateral and rear end impact loading: modelling and validation. PhD Thesis, Eindhoven University of Technology, Eindhoven, The Netherlands, 2002. 
2 van Lopik, D. W. A computational model of the human head and cervical spine for dynamic impact simulation. $\mathrm{PhD}$ Thesis, Loughborough University, Loughborough, UK, 2004.

3 López-Valdés, F., Mansilla, A., Martín, R., and Muñoz, D. A study of current neck injury criteria used for whiplash analysis. Proposal of a new criterion involving upper and lower neck load cells. In Proceedings of the 19th International Technical Conference on Enhanced Safety of Vehicles, Washington DC, USA, 2005, paper 05-0313-O.

4 Jakobsson, L., Norin, H., Jernström, C., Svensson, S.-E., Johnsen, P., Isaksson-Hellman, I., and Svensson, M. Y. Analysis of different head and neck responses in rear-end car collisions using a new humanlike mathematical model. In Proceedings of International IRCOBI Conference, 1994, Lyon, France, pp. 109-125.

5 de Jager, M. K. J. Mathematical head-neck models for acceleration impacts. $\mathrm{PhD}$ Thesis, Eindhoven University of Technology, Eindhoven, The Netherlands, 1996.

6 van den Kroonenberg, A., Thunnissen, J., and Wismans, J. A human model for low-severity rearimpacts. In Proceedings of International IRCOBI Conference, Hannover, Germany, 1997, pp. 117-132.

7 Yamazaki, K., Ono, K., and Kaneoka, K. A simulation analysis of human cervical spine motion during low speed rear-end impacts. SAE paper 2000-01-0154, 2000.

8 Linder, A. A new mathematical neck model for a low-velocity rear-end impact dummy: Evaluation of components influencing head kinematics. Accid. Analysis and Prev., 2000, 32(2), 261-269.

9 Stemper, B. D., Yoganandan, N., and Pintar, F. A. Validation of a head-neck computer model for whiplash simulation. Med. Biol. Engng Computing, 2004, 42(3), 333-338.

10 Happee, R., Ridella, S., Nayef, A., Morsink, P., de Lange, R., Bours, R., and van Hoof, J. Mathematical human body models representing a mid size male and a small female for frontal, lateral and rearward impact loading. In Proceedings of International IRCOBI Conference, Montpellier, France, 2000, pp. 67-85.

11 Stemper, B. D., Yoganandan, N., and Pintar, F. A. Gender dependent cervical spine segmental kinematics during whiplash. J. Biomechanics, 2003, 36(9), 1281-1289.

12 Davidsson, J., Deutscher, C., Hell, W., Linder, A., Lövsund, P., and Svensson, M. Y. Human volunteer kinematics in rear-end sled collisions. In Proceedings of the International IRCOBI Conference, Göteborg, 1998, Sweden, pp. 289-301.

13 Davidsson, J., Ono, K., Inami, S., Svensson, M. Y., and Lövsund, P. A Comparison between volunteer, BioRID P3 and Hybrid III performance in rear impacts. In Proceedings of International IRCOBI Conference, 1999, Sitges, Spain, pp. 165-178.

14 Hynd, D. and van Ratingen, M. Challenges in the development of a regulatory test procedure for neck protection in rear-end impacts: status of the EEVC WG20 and WG12 joint activity. In Proceedings of the 19th International Technical Conference on Enhanced Safety of Vehicles, Washington DC, USA, 2005, paper 05-0048-O.

15 Hynd, D., Willis, C., and Roberts, A. TRL rear impact volunteer testing: methods and measurements. APSN Biomechanics Workshop, 2004, Graz, Austria.

16 van den Kroonenberg, A., Philippens, M., Cappon, H., Wismans, J., Hell, W., and Langwieder, K. Human head-neck response during low-speed rear end impacts. SAE paper 983158 , 1998.

17 Siegmund, G. P., Heinrichs, B. E., Lawrence, J. M., and Philippens, M. M. G. M. Kinetic and kinematic responses of the RID2a, Hybrid III and human volunteers in low-speed rear-end collisions. In Proceedings of the 45th Stapp Car Crash Conference, 2001, San Antonio, Texas, USA, pp. 239-256, SAE paper 2001-22-0011.

18 Bertholon, N., Robin, S., Le Coz, J.-Y., Potier, P., Lassau, J. P., and Skalli, W. Human head and cervical spine behaviour during low-speed rear-end impacts: PMHS sled tests with a rigid seat. In Proceedings of the International IRCOBI Conference, 2000, Montpellier, France, pp. 265-277.

19 Viano, D. C., Hardy, W. N., and King, A. I. Response of the head, neck and torso to pendulum impacts on the back. Crash Prevention and Injury Control, 2001, 2(4), 289-306.

20 Ono, K., Kaneoka, K., Wittek, A., and Kajzer, J. Cervical injury mechanism based on the analysis of human cervical vertebral motion and head-necktorso kinematics during low-speed rear impacts. SAE paper 973340, 1997.

21 Davidsson, J., Svensson, M. Y., Flogård, A., Håland, Y., Jakobsson, L., Linder, A., Lövsund, P., and Wiklund, K. BioRID I-a new biofidelic rear impact dummy. In Proceedings of the International IRCOBI Conference, 1998, Göteborg, Sweden, pp. 377-390.

22 Klinich, K. D., Ebert, S. M., van Ee, C. A., Flannagan, C. A. C., Prasad, M., Reed, M. P., and Schneider, L. W. Cervical spine geometry in the automotive seated posture: variations with age, stature and gender. SAE paper 2004-22-0014, 2004.

23 Amevo, B., Worth, D., and Bogduk, N. Instantenous axes of rotation of the typical cervical motion segments: a study in normal volunteers. Clin. Biomech., 1991, 6, 111-117.

24 van Mameren, H., Sanches, H., Beursgens, J., and Drukker, J. Cervical spine motion in the sagittal plane II: Position of segmental averaged instantenous centers of rotation-a cineradiographic study. Spine, 1992, 17, 467-474.

25 Kaneoka, K., Ono, K., Inami, S., Hayashi, K., and Bogduk, N. Motion analysis of cervical vertebrae during whiplash loading. Spine, 1999, 24(8), 763-769.

26 Dvorak, J., Panjabi, M. M., Novotny, J. E., and Antinnes, J. A. In vivo flexion/extension of the normal cervical spine. J. Orthop. Res., 1991, 9, 828-834. 
27 Ono, K., Kaneoka, K., and Inami, S. Influence of seat properties on human cervical vertebral motion and head/neck/torso kinematics during rear-end impacts. In Proceedings of the International IRCOBI Conference, 1998, Göteborg, Sweden, pp. 303-318.

28 Kaneoka, K., Ono, K., Inami, S., Ochiai, N., and Hayashi, K. The human cervical spine motion during rear-impact collisions: a proposed cervical facet injury mechanism during whiplash trauma. J. Whiplash \& Related Disorders, 2002, 1(1), 85-98.

29 Kingma, H., Patijn, J., de Jong, I., Gosens, H. W., Stevens, J., Dekker, A., Lansbergen, M., van der Horst, M., Wismans, J., and van Mameren, $\mathbf{H}$. Impact of muscle contraction upon head stabilisation during sudden forward acceleration. Maastricht University Report, 2002.

30 Wismans, J., Philippens, M., van Oorschot, E., Kallieris, D., and Mattern, R. Comparison of human volunteer and cadaver head-neck response in frontal flexion. In Proceedings of the 31st Stapp Car Crash Conference, 2001, San Antonio, Texas, USA, pp. 239-256, SAE paper 872194.

31 Kumar, S., Ferrari, R., and Narayan, Y. Kinematic and electromyographic response to whiplash loading in low-velocity whiplash impacts-a review. Clin. Biom., 2005, 20(4), 343-356.

32 Viano, D. C. and Davidsson, J. Neck displacements of volunteers, BioRID P3 and Hybrid III in rear impacts: implications to whiplash assessment by a neck displacement criterion (NDC). Traff. Injury Prev., 2002, 3(2), 105-116.

\section{APPENDIX}

\section{Notation}

ATD

BioRID

BioRID II P3

C.G.

delta-V (Dv)

EMG

$\mathrm{g}$

Hybrid III (H III)

IAR

JARI

Madymo

OC

SCM

T1

TNO anthropometric test device (dummy)

biofidelic rear impact dummy commercial version of BioRID centre of gravity velocity change of a vehicle subjected to a crash pulse electromyography gravitational acceleration $\left(\mathrm{m} / \mathrm{s}^{2}\right)$

frontal crash test dummy instantaneous axis of rotation between adjacent vertebrae Japanese Automobile Research Institute integrated multi-body finiteelement package of TNO occipital condyles sternocleidomastoid first thoracic vertebra TNO Automotive, Crash Safety Centre, Delft, The Netherlands 